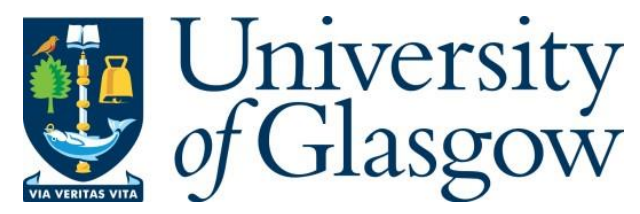

Vanatta, S. H. (2020) Histories of Bank Supervision. Bank Supervision: Past, Present, and Future, 11 Dec 2020.

There may be differences between this version and the published version. You are advised to consult the publisher's version if you wish to cite from it.

$\underline{\text { http://eprints.gla.ac.uk/236445/ }}$

Deposited on: 16 March 2021

Enlighten - Research publications by members of the University of Glasgow http://eprints.gla.ac.uk 


\title{
Histories of Bank Supervision
}

\author{
Sean H. Vanatta^ \\ University of Glasgow
}

\section{Introduction}

In the United States, supervision is as old as banking, or nearly as old. State governments developed oversight regimes in the decades before the Civil War, and the federal government has played a permanent supervisory role since that conflict. In this, the United States is unique. Except for Sweden (1909) and Japan (1916), most developed nations formalized bank supervision only after the 1930 s banking crises, sometimes well after. ${ }^{1}$

Yet, despite its long history in the United States, supervision-most simply, the various and sometimes conflicting tools government officials use to shape individual bank behaviorhas not been a significant topic for U.S. historians. This neglect is not surprising. Supervision and supervisors are chameleon-like. Supervision resembles a number of well-studied governance mechanisms-regulation, civil and criminal litigation, self-regulation, even ethics. Indeed, it is often confused with them. At the same time, like chameleons, supervisors prefer to stay hidden. In part, this is an institutional legacy of the nineteenth-century modes of governance from which supervision emerged. In that period, historian Brian Balogh argues, American policymakers maintained a robust regulatory state "out of sight," hidden from an electorate that remained as suspicious of standing bureaucracies as of standing armies. ${ }^{2}$ Camouflage was a survival strategy. Since the New Deal in the 1930s, supervisors have been more visible, thanks to new institutions like the Federal Deposit Insurance Corporation. Nevertheless, supervisors have largely taken invisibility as a virtue. Meanwhile, much of supervision's paper trail remains obscured and inaccessible, labelled as "Confidential

\footnotetext{
- This work builds on, but is distinct from, my ongoing project with Peter Conti-Brown, Risk and Discretion: A History of Bank Supervision in the United States (Harvard University Press, forthcoming).

${ }^{1}$ Richard S. Grossman, Unsettled Account: The Evolution of Banking in the Industrialized World since 1800 (Princeton University Press, 2010), 162-167, 221-222; Eiji Hotori and Mikael Wendschlag, "The Formalization of Bank Supervision in Japan and Sweden,” Social Science Japan Journal 22, no. 2 (Summer 2019): 212, 215; Patrice Baubeau, Eric Monnet, Angelo Riva, and Stefano Ungaro, "Flight-to-Safety and the Credit Crunch: A New History of the Banking Crises in France during the Great Depression," Economic History Review (forthcoming).

2 Brian Balogh, A Government Out of Sight: The Mystery of National Authority in Nineteenth-Century America (Cambridge University Press, 2009).
} 
Supervisory Information." Thus, the few scholars who have identified supervision as a topic of inquiry have trouble seeing beyond the published reports.

A further reason for scholarly neglect specifically among historians has less to do with the subject and more to do with the investigators. As is well known, in the United States the disciplines of history and economic history suffered an acrimonious break over cliometrics in the 1960 s and 1970 s. $^{3}$ Historians then largely turned their attention towards previously excluded groups and cultural topics. 4 The discipline was richer for this turn, but historical political economy, and associated sub-fields like business history and policy history, became niche undertakings-at least in the American academy. Like economic historians, practitioners of these sub-fields often made their careers outside of history departments. The rifts, thankfully, are mending. Legal historians, political historians, and historical political scientists working in the American Political Development tradition have all shown renewed interest in the governance mechanisms of the nineteenth-century state, where supervision has its origins. ${ }^{5}$ Likewise, scholars working under the rubric of the "New History of Capitalism" have turned attention toward the relationships between finance and American governance. ${ }^{6}$ Neither of these groups has yet converged on supervision, but their research questions necessarily lead in that direction.

In this essay, I will make the case for the historical study of supervision-both that historical methods are necessary to understanding the shape and structure of supervision in the present and that the study of supervision will contribute to active and important historiographical debates. First, I will summarize how scholars-including my own work, with Peter Conti-Brown-are grappling with the definitional complexities of supervision as a set of layered, overlapping, and contingent governing practices. I will then survey the extant sources of supervisory history; briefly because they are so few, largely comprised of institutional histories

\footnotetext{
3 Naomi Lamoreaux, "Beyond the Old and the New: Economic History in the United States," in Routledge Handbook of Global Economic History, Francesco Boldizzoni and Pat Hudson, eds. (Routledge, 2016).

4 Peter Novick, That Noble Dream: The "Objectivity Question" and the American Historical Profession (Cambridge University Press, 1988), 588-589.

5 For a helpful overview of this literature, see William J. Novak, “The Myth of the 'Weak' American State," The American Historical Review 113, no. 3 (June 1, 2008): 752-72. For important recent works, see Balogh, $A$ Government Out of Sight; Jerry L. Mashaw, "Federal Administration and Administrative Law in the Gilded Age," 119 Yale Law Journal 1362 (2010); Nicholas R. Parrillo, Against the Profit Motive: The Salary Revolution in American Government, 1780-1940 (Yale University Press, 2013).

${ }^{6}$ For a general starting point, see "Interchange: The History of Capitalism," Journal of American History 101, no. 2 (September 1, 2014): 503-36; for critique, see Eric Hilt, "Economic History, Historical Analysis, and the 'New History of Capitalism," Journal of Economic History 77, no. 2 (June 2017): 511-536; and for the direction of the agenda, see Slavery's Capitalism: A New History of American Economic Development, Sven Beckert and Seth Rockman, eds. (University of Pennsylvania Press, 2016); Kenneth Lipartito, "Reassembling the Economic: New Departures in Historical Materialism," The American Historical Review 121, no. 1 (February 1, 2016): 101-139; Caitlin Rosenthal, "Capitalism when Labor was Capital: Slavery, Power, and Price in Antebellum America," Capitalism: A Journal of History and Economics 1, no. 2 (Spring 2020): 296-337 [And this journal, generally].
} 
of supervisory institutions, as well as memoirs and biographies of practitioners. Finally, I will offer a prospective historical agenda, in two parts. I will narrate a history of supervision in the United States through the New Deal to demonstrate where the history of supervision, once further developed, will contribute to debates about co-development of financial institutions and regulatory governance. Then, I will suggest ways that supervisory history can also enrich-and be enriched by-histories of science, gender, race, and sexuality. In sum, this essay suggests paths forward, for scholars for whom bank supervision is self-evidently important, and for those who may have never encountered the term before.

\section{Supervision: A Provisional Definitional Typology}

What, after all, is supervision? And what makes it distinct from other modes of governance? Given its chameleon-like character, supervision is most often confused with regulation, but the two are different functions entirely. Defining regulation is easy enough: regulation, to take the Federal Reserve's 2016 definition, “entails establishing the rules within which financial institutions must operate-in other words, issuing specific regulations and guidelines governing the formation, operations, activities, and acquisitions of financial institutions.” More simply, regulations are rules. Shifting to supervision, the Fed continues: “Once the rules and regulations are established, supervision-which involves monitoring, inspecting, and examining financial institutions-seeks to ensure that an institution complies with those rules and regulations, and that it operates in a safe and sound manner."7 Thus, if regulation involves rules, supervision entails the tools government officials use to ensure financial firms comply with the rules.

The Fed's 2016 definition of supervision is at once expansive and limited. It is expansive in that each of the actions ascribed to supervision-monitoring, inspecting, and examiningcontain in them a host of subsidiary practices, which supervisors use to shape behavior: to guide, to suggest, to demand, and to compel. The definition is limited in its implicit claim that supervision is only the implementation of law; it is only compliance with rules.

The narrowness of the Fed's 2016 definition becomes visible when it is placed against an earlier-and much longer-one, published by the Fed in 1954. "As a governmental activity, bank supervision encompasses a wide variety of technical functions relating to the operations of

\footnotetext{
7 Board of Governors of the Federal Reserve System, The Federal Reserve System: Purposes and Functions, $10^{\text {th }}$ ed. (Board of Governors, 2016), 72
} 
banks," it begins. ${ }^{8}$ Among these functions, the Fed listed "the periodic examination of banks and the requiring of steps by bank management to correct unsatisfactory or unsound conditions;" "the review and analysis of periodic reports of condition;" "the rendering of counsel and advice on bank operating problems;" "the appointment of a conservator under certain conditions or a receiver in other circumstances;" and many other activities. Instead of just monitoring, inspecting, and examining -the passive oversight of 2016-in 1954, the Fed put forward an active version of supervisory governance, not just examining, but requiring correction; not just reviewing, but analyzing; not just implementing the law, but rendering counsel and advice. Here, the supervisory purview was much wider than mere compliance. Supervisors assertively deployed official judgement and discretion, often to mold behavior according to preferences and objectives that were distinct from any formal rules.

The transformation evident in these definitions, from an active, self-confident government in 1954, to a chastened, restrained government in 2016, maps rather transparently onto the consensus narrative of the American state, activist in the wake for the New Deal, retrenched following the Reagan Revolution. ${ }^{9}$ Yet, although the competing definitions seem to suggest the diminution of supervisory authority over this span, just the opposite has happened. ${ }^{10}$ The Fed's 2016 equation of supervision with legal compliance thus reflects a choice among definitional alternatives, one that may indicate changing views about the role of government in the economy, institutional changes to the supervisory purview of the Federal Reserve, or personnel changes in the authorship of The Federal Reserve: Purposes and Functions, from which the definitions were drawn. These changes require historical explanation.

Scholars have recently begun to pursue this work, most often to build historical foundations for normative claims about how supervision should function in the present. Economic historian Eugene White, for example, views federal supervision as a constant tug between regimes which embrace strictly rules-based, market discipline-his preference-and

\footnotetext{
${ }^{8}$ Board of Governors of the Federal Reserve System, The Federal Reserve System: Its Purposes and Functions, $3^{\text {rd }}$ ed. (Board of Governors, 1954), 166-167, https://fraser.stlouisfed.org/title/federal-reserve-system-1204. This definition, slightly expanded and broken into multiple paragraphs, appeared again in 1961. For the full purposes and functions series, see: https://fraser.stlouisfed.org/series/federal-reserve-system-4526. For contemporaneous discussion of the expansive purview of supervision, see Robert F. Leonard, "Supervision of the Commercial Banking System" and Leo H. Paulger, "Policy and Procedure in Bank Examination," in Banking Studies, E. A. Goldenweiser, Elliot Thurston, and Bray Hammond, eds. (Baltimore, 1941).

9 The literature on the transformation of regulatory governance in the postwar era is broad and diverse. Key texts include, narrowly, Martha Derthick and Paul J Quirk, The Politics of Deregulation (Brookings Institution, 1985); Richard A. Harris and Sidney M. Milkis, The Politics of Regulatory Change: A Tale of Two Agencies, 2nd ed (Oxford University Press, 1996), and broadly, David Harvey, A Brief History of Neoliberalism (Oxford University Press, 2005).

${ }^{10}$ Conti-Brown and Vanatta, Risk and Discretion.
} 
those which rely more heavily on supervisory discretion. ${ }^{11}$ Economic historians Charles Calomiris and Mark Carlson see the role of examiner in the late $19^{\text {th }}$ century in a similar way, focusing primarily on their roles in risk management and information disclosures. ${ }^{12}$

Legal scholars, meanwhile, have used history to understand the present legal structures in a more systematic, consistent way. ${ }^{13}$ For example, Lev Menand offers a variety of taxonomic categories-“Supervisors as Rule Enforcers," "Discipline Facilitators," "Gap Fillers," among others. But the historical record often resists such stability, as Menand notes: bank supervision, as with banking law generally, is "theoretically adrift." Menand's effort, consistent with a growing scholarly tradition at the intersection of law, economics, and history sometimes called "the money view," would systematize supervision under a different, normative framework: Supervisors are "franchisors," guardians of the monetary franchise outsourced by the government to banks. ${ }^{14}$

These theories of supervision, that draw on supervision's rich past, are self-consciously normative: that is, they want to define what supervision should be. What they lack is a more historically-rooted account of what supervision has been (and, to the extent that this includes the present, what it is, in fact). In work with Peter Conti-Brown on the history of bank supervision, we offer a typology of supervision that tries to capture its range of functions., The typology has two parts. First, supervision functions as a distinct mechanism of legal obediencea means by which government or private actors seek to alter behavior. These mechanisms can be displayed on two axes, between public and private mechanisms, which require the exercise of coercive and non-coercive power. In this sense, supervision represents a choice for policymakers-principally, but not exclusively, Congress-distinct from other alternatives. It is a choice, as the graphic indicates, which authorizes government officials to exercise substantial discretion about how to alter behavior. To return to the Fed's 1954 definition, this can take the form of "the rendering of counsel and advice (private, non-coercive)," "requiring of steps by

\footnotetext{
${ }^{11}$ Eugene N. White, "Lessons from the History of Bank Examination and Supervision in the United States, 18632008," https://papers.ssrn.com/sol3/papers.cfm?abstract_id=2101709.

${ }^{12}$ Charles W. Calomiris and Mark Carlson, "Bank Examiners' Information and Expertise and Their Role in Monitoring and Disciplining Banks Before and During the Panic of 1893," NBER Working Paper No. w24460 (March 2018), https://www.nber.org/papers/w24460.

${ }^{13}$ See Julie Hill's separate literature review for this conference for additional legal scholars' engagements here, but of particular note are Rory Van Loo, "Regulatory Monitors: Policing Firms in the Compliance Era," Columbia Law

Review 119 (2019): 369-444; and Jeremy Kress, "Solving Banking's 'Too Big to Manage' Problem," Minnesota Law Review 104 (2019): 171-241.

14 Lev Menand, "Why Supervise Banks? The Forgotten Past and Uncertain Future of a Distinctive Form of Governance," Vanderbilt Law Review (forthcoming), 1, 15, 31, 78. The key works in the Money View include Hyman P. Minsky, Stabilizing an Unstable Economy: A Realistic Approach to Economic Theory (Yale University Press, 1986); Christine A. Desan, Making Money: Coin, Currency, and the Coming of Capitalism (Oxford University Press, 2014); and Morgan Ricks, The Money Problem: Rethinking Financial Regulation (University of Chicago Press, 2015).
} 
bank management to correct unsatisfactory or unsound conditions found through such examination (private, coercive)," or "the liquidation of banks (public, coercive)." 15

Figure 1 - Paradigms of Supervision: External

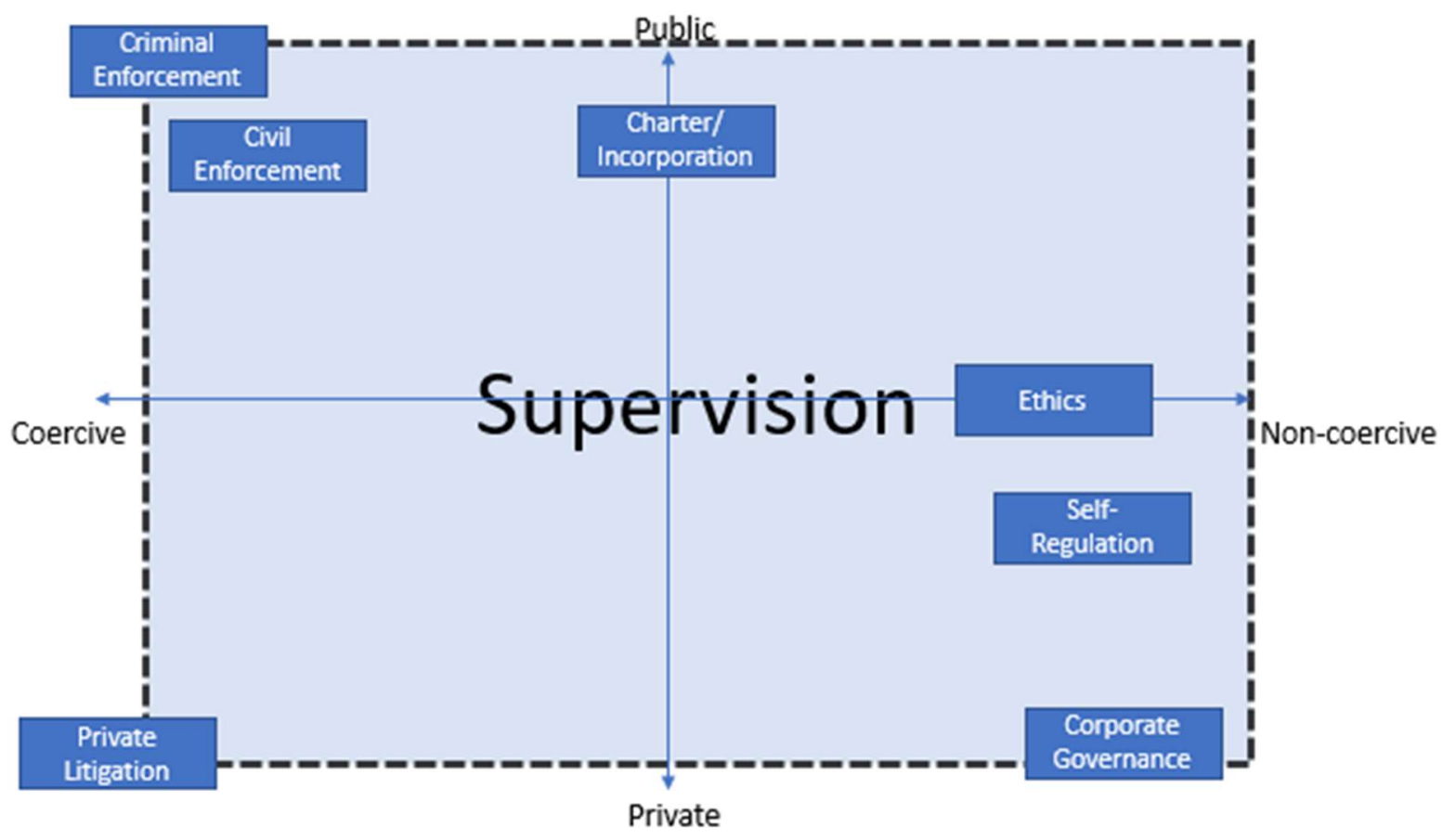

Relatedly, what supervision is hinges on what supervisors' think they are trying to accomplish, self-conceptions that divide not only according to an external logic of coercion vs. non-coercion and public vs. private, but also an internal one. These self-conceptions operate within a framework with axes spanning punitive to collaborative and from retrospective to prospective, as summarized in Figure 2. The alternatives presented here are evident in the 1954 definition, and they become even more visible when comparing it with its 2016 counterpart. In 1954, to take just one example, the Fed emphasized "the rendering of counsel and advice on bank operating problems when requested, particularly in the case of smaller banks," a statement that embraces the training and management consulting roles on the collaborative-prospective corner of the chart. Although the Fed may have been engaged in similar activities in 2016, it no longer held them as a defining feature of compliance-focused supervision.

15 Conti-Brown and Vanatta, Risk and Discretion. 
Figure 2 - Paradigms of Supervision: Internal

Police
Retrospective

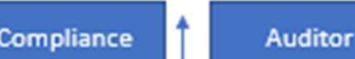

Risk Manager

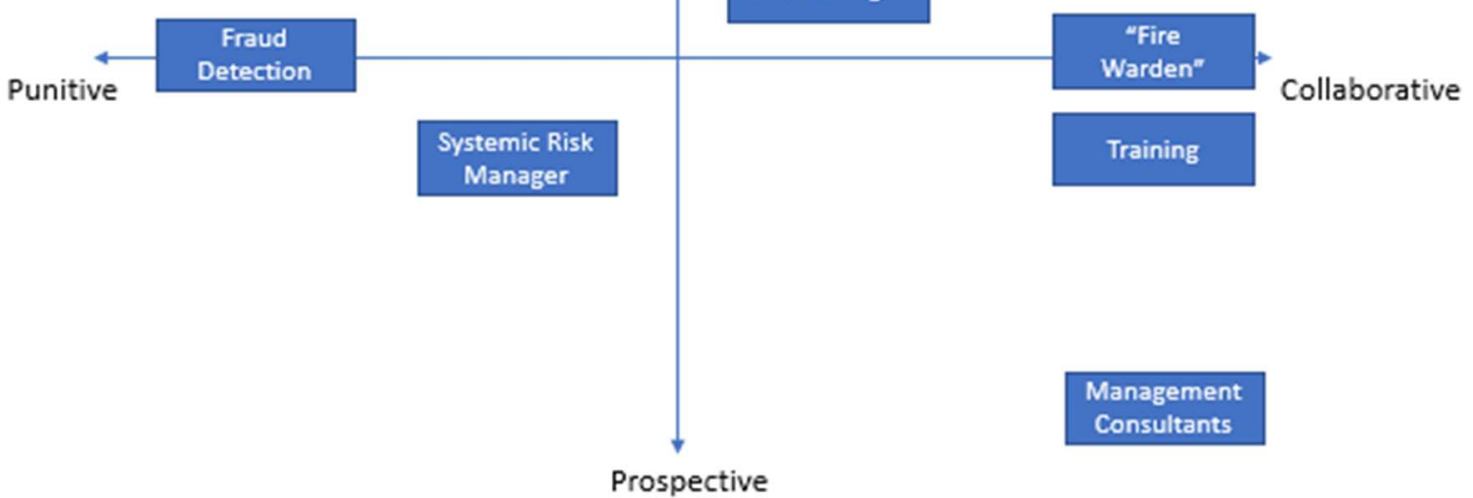

This conception of supervision captures some of the descriptive and normative accounts of scholars like White, Calomiris \& Carlson, and Menand, without rooting that conception too much in a single point of time and imposing that moment on the rest of history. As a policy matter, the virtues (vices) of the Fed's expansive view of supervision in 1954 and more circumscribed view in 2016 are open to debate. And that debate must rest on a richer body of scholarly evidence than this mere definitional exercise can provide. The work of history is to understand the range of possible choices supervisors faced and why-given the inherent discretion-supervisors made the choices they did.

\section{Institutional Histories, Memoirs, and Biographies}

Whatever one's definitional commitments to understanding supervision, the next step for historians is to understand who supervisors were, what they did when they were supervising, and who received (and reacted to) that supervision. Much of the extant historical scholarship on supervision takes the form of official histories, most recently by the Comptroller of the Currency 
and Federal Deposit Insurance Corporation. ${ }^{16}$ As institutional histories, these volumes provide narrative accounts that are reflective but not critical. (Several Federal Reserve Banks have also produced histories, which are often more celebratory than even reflective, and which seldom cover supervision in significant depth. ${ }^{17}$ )

Perhaps the most useful accounts produced in the institutional vein are those written under the auspices of the National Monetary Commission in the early 1910s, examining antebellum state and early federal supervision. ${ }^{18}$ Given their publication before the founding of the Federal Reserve, these volumes necessarily fail to analyze recent supervisory experience, but remain foundational to understanding the nineteenth-century supervisory system.

Likewise, practitioner memoirs and biographies provide another vantage on supervision, offering at once historical accounts of supervisory policies and practices, as well as insight into the core ideas and political tensions that shaped supervision. These works tend to cluster around significant economic and political episodes, moments when protagonists or their biographers recognized that major change had taken place. Thus, institutional foundings and founders feature prominently, especially those of the Comptroller of the Currency and the Federal Reserve. ${ }^{19}$ We also have considerable material covering the 1930 s banking crises and the New Deal, which in its way functioned as re-founding of federal supervision in the wake of the Great Depression. ${ }^{20}$ There has also been a wealth of material on the failures of supervision, clustered

\footnotetext{
${ }^{16}$ Ross M. Robertson, The Comptroller and Bank Supervision: A Historical Appraisal, $2^{\text {nd }}$ ed. (Office of the Comptroller of the Currency, 1995); Federal Deposit Insurance Corporation, ed., Federal Deposit Insurance Corporation: The First Fifty Years: A History of the FDIC, 1933-1983 (FDIC, 1984).

17 John A. Griswold, A History of the Federal Reserve Bank of Chicago (J. Mulligan, 1936); Joseph H. Taggart, The Federal Reserve Bank of Boston (Bankers Publishing Company, 1938); Jacksonville Branch, Federal Reserve Bank of Atlanta (The Federal Reserve Bank of Atlanta, 1952); Richard H. Gamble, A History of the Federal Reserve Bank of Atlanta, 1914-1989 (The Federal Reserve Bank of Atlanta, 1989); Federal Reserve Bank of Chicago, Historical Perspectives: The Bank at 75, 1914-1989 (The Federal Reserve Bank of Chicago, 1989); Diane Shephard, Federal Reserve Bank of Boston (Arcadia Publishing, 2014).

18 Relevant volumes include Robert E. Chaddock, The Safety Fund Banking System in New York, $1829-1866$ 61 Cong. Doc. No. 581 (1910); Davis R. Dewey, The Second United States Bank 61 Cong. Doc. No. 571 (1910); Davis R. Dewey, State Banking Before the Civil War 61 Cong. Doc. No. 581 (1910); John Thom Holdsworth, The First Bank of the United States 61 Cong. Doc. No. 571 (1910); David Kinley, The Independent Treasury of the United States and Its Relations to the Banks of the Country 61 Cong. Doc. No. 587 (1910);O. M. W. Sprague, History of Crises under the National Banking System 61 Cong. Doc No. 538.

19 For the National Banking system, see Hugh McCulloch, Men and Measures of Half a Century (Charles Scribner's Sons, 1889); John Sherman, John Sherman's Recollections of Forty Years in the House, Senate, and Cabinet: An Autobiography. For the Federal Reserve, see Paul Warburg, The Federal Reserve System: Its Origins and GrowthReflections and Recollections (Macmillan, 1930); Carter Glass, An Adventure in Constructive Finance (Doubleday, 1927); Matthew P. Fink, The Unlikely Reformer: Carter Glass and Financial Regulation (George Mason University Press, 2019); H. Parker Willis, The Federal Reserve: Legislation, Organization and Operation (Ronald Press, 1923). ${ }^{20}$ James Francis Thaddeus O'Connor, The Banking Crisis and Recovery under the Roosevelt Administration (Capo Press, 1938); Frances Gloyd Awalt, "Recollections of the Banking Crisis in 1933," Business History Review 43, no. 3 (Autumn 1969): TK; George W. Norris, Ended Episodes (Philadelphia, 1937); Sidney Hyman, Marriner S. Eccles, Private Entrepreneur and Public Servant (Stanford, California: Graduate School of Business, Stanford University, 1976); Marriner S. Eccles, Beckoning Frontiers; Public and Personal Recollections, Sidney Hyman, ed. (Knopf, 1966); Mark Wayne Nelson, Jumping the Abyss: Marriner S. Eccles and the New Deal, 1933-1940 (University of Utah Press,
} 
especially around the 1980 s Savings \& Loan Crisis, the Continental Illinois failure, and the 2008 Financial Crisis. ${ }^{21}$ (Auto)biographical accounts are indispensable historical sources, but they are also limited in several respects. Memoir writers and biographers tend to overemphasize their or their subjects place in historical events, while memoirists, understandably, misremember. Meanwhile, there are few accounts of supervisory lives outside the spotlight of major events. ${ }^{22}$

Even so, the richness of these records is sometimes rather extraordinary. For example, the recollections of Acting Comptroller Frances G. Awalt and Philadelphia Federal Reserve Bank Governor George W. Norris, humanize the immense and unrelenting pressure supervisors experienced during the Banking Holiday of 1933. Once Franklin Roosevelt placed the national recovery squarely on the supervisory apparatus, promising the public that only sound banks would reopen, supervisors worked fanatically to make life and death decisions about the fate of each of the nation's banks. "Sleep was practically unknown to many of us," Awalt recalled. The task, Norris relates, was "so onerous and responsible, and performed under such a cruel limitation of time," that the head examiner at the Philadelphia Fed suffered a breakdown that "compelled him to rest for a year before his health was completely restored." ${ }^{23}$

\section{Supervision and Governance: A Prospective Narrative}

The institutional histories, memoirs, and biographies described above shine important light on the transformation of supervisory governance over time, but they also largely stand outside existing historical debates, especially those about financial development and regulatory governance, to which supervisory histories will be most relevant. Below, then, I narrate a prospective history of supervision in the United States, emphasizing the ways research in this

2017); Stuart L. Weiss, The President's Man: Leo Crowley And Franklin Roosevelt in Peace and War (Southern Illinois University Press, 1996); William A. Keleher, Memoirs: 1892-1969, A New Mexico Item (Rydal Press, 1969). ${ }^{21}$ On the S\&L Crisis, see Lewis William Seidman, Full Faith and Credit: The Great $S$ \& L Debacle and Other Washington Sagas (Times Books, 1993); William E. King, Saving Face: An Alternative and Personal History of the Savings and Loan Crisis (Somerset Publications, 2008); Irving Sprague, Bailout: An Insider's Account of Bank Failures and Rescues (Beard Books, 2000); Lawrence J. White, The S\&L Debacle: Public Policy Lessons for Bank and Thrift Regulation (New York: Oxford University Press, 1991). On Continental Illinois, see William L. Silber, Volcker: The Triumph of Persistence (Bloomsbury Press, 2012); Paul A. Volcker with Christine Harper, Keeping at It: The Quest for Sound Money and Good Government (Public Affairs, 2018). For the 2008 financial crisis, see Timothy F. Geithner, Stress Test: Reflections on Financial Crisis (Random House, 2015); Ben S. Bernanke, The Courage to Act: A Memoir of a Crisis and its Aftermath (W. W. Norton, 2017); Sheila Bair, Bull by the Horns: Fighting to Save Main Street from Wall Street and Wall Street from Itself (Simon \& Schuster, 2013).

${ }^{22} \mathrm{Cf}$. Thomas P. Kane, The Romance and Tragedy of Banking; Problems and Incidents of Governmental Supervision of National Banks, 2d ed (The Bankers Publishing Co, 1923).

23 Awalt, "Recollections of the Banking Crisis," 369n6; Norris, Ended Episodes, 232-233. (on this, generally, see Peter Conti-Brown and Sean H. Vanatta, "The Logic and Legitimacy of Bank Supervision: The Case of the 1933 Bank Holiday," Business History Review [forthcoming].) 
field intersects with ongoing debates about financial governance before and through the New Deal era. In effect, the narrative also describes the steady accretion of positions on the definitional paradigm provided above, both external mechanisms of legal obedience and internal ideologies guiding supervisory practice.

The history of supervision in the United States necessarily begins in the antebellum period, when state governments tentatively experimented with different forms of financial oversight. ${ }^{24}$ The first was chartering, which at the level of the individual bank gave states the opportunity to evaluate the intentions and capacity of entrepreneurs before authorizing them to conduct business. Charters were often also of limited duration, so the chartering authority had successive opportunities to reconsider a banking firm's existence. Conceptualizing charting as supervision aligns it with the broad literature on the ways that weak state and local governments combined private initiative and the corporate form to promote public development in the eighteenth and nineteenth centuries. ${ }^{25}$ During this period, states also developed supervisory tools to monitor banks once they had opened for business. Under the umbrella of the ill-fated Safety Fund-an early liability insurance scheme-New York instituted the first examination system in $1829 .{ }^{26}$ Although the Safety Fund went bankrupt following the Panic of 1837, examination remained in place in New York and expanded to other states, sometimes executed by state officials and sometimes undertaken by other bankers. ${ }^{27}$ Bankers also organized "selfregulatory" institutions like the Suffolk-system and the New York Clearinghouse (perhaps more properly called self-supervisory systems). ${ }^{28}$ Thus, overlapping supervisory authority in the present is not so much a new feature as merely a different constellation of competing supervisory institutions.

Much of this supervisory energy - and with it the external supervisory tools-was directed at maintaining sound, bank-issued currencies, yet states also gave supervisory officials wider mandates, the scope of which remain to be fully explored. On the one hand, what we

24 On antebellum period generally, see Bray Hammond, Banks and Politics in America from the Revolution to the Civil War (Princeton University Press, 1957); Howard Bodenhorn, A History of Banking in Antebellum America: Financial Markets and Economic Development in an Era of Nation-Building (Cambridge University Press, 2000 ). 25 This literature is most fully developed as the so-called "Commonwealth" school. For an overview, see Harry Scheiber, "Government and the Economy: Studies of the 'Commonwealth' Policy in Nineteenth-Century America." The Journal of Interdisciplinary History 3, no. 1 (1972): 135-51.

${ }^{26}$ Chaddock, The Safety Fund Banking System in New York; Howard Bodenhorn, "Zombie Banks and the Demise of New York's Safety Fund," Eastern Economic Journal 22, no. 1 (Winter 1996): 21-33.

27 Warren Weber, “Bank Liability Insurance Schemes Before 1865," Research Department, Federal Reserve Bank of Minneapolis Working Paper No. 679 (2011).

${ }_{28}$ J. S. Gibbons, The banks of New York, their dealers, the clearing house, and the Panic of 1857 (D. Appleton, 1858); Wilfred S. Lake, "The End of the Suffolk System," The Journal of Economic History 7, no. 2 (November 1947): 183207; Arthur J. Rolnick, Bruce D. Smith, and Warren E. Weber, "The Suffolk Bank and the Panic of 1837," Federal Reserve Bank of Minneapolis Quarterly 24, no. 2 (Spring 2000). 
might call the market mechanism of note redemption - the act or threat of physically appearing at a bank and demanding specie payment in exchange for its notes-served as an active check on excessive note issue by private banks. Note redemption, however, was not only the province of private actors. It operated through a variety of channels: undertaken at times by public officials, by quasi-public institutions like the First and Second Banks of the United States, by selfsupervisory institutions, by bank counterparties, and by the unsophisticated public. ${ }^{29}$ The extent to which any of these actors thought of note redemption as fundamentally or partially supervisory, concerned in some sense with maintaining the lager currency system, is debatable-and indeed remains to be examined and debated. States also envisioned more than the mere monitoring private banks' currency issues. Beginning in 1838, New York bank commissioners were charged with "ascertaining the safety of [a bank's] investments and the prudence of its management."30 The mandate reflected both a new external task and a new internal motivation. The legislature invited examiners to not only take a retrospective view of notes a bank had already issued, but also to take a prospective view of a bank's management to guide it toward prudence in the future.

The antebellum story lays the groundwork for the founding of the national banking system during the Civil War, the first robust federal effort at banking supervision. For scholars of American political development, the Civil War was a major turning point, when the United States developed an assertive federal bureaucracy. On first inspection, supervision fits well within this narrative. The national banking system was a central pillar supporting the northern political economy. ${ }^{31}$ The Comptroller of the Currency headed a new bureaucracy, given life during the conflict and momentum to expand thereafter.

Yet, supervisory history also suggests opportunities to rethink this grand narrative in line with recent revisionary efforts. ${ }^{2}$ First, there may be an antebellum story of federal financial oversight in need of recovery. Treasury Department supervision of the First and Second Banks of the United States may have provided a vector for government officials to influence these

\footnotetext{
${ }^{29}$ Jane Kamensky, The Exchange Artist: A Tale of High-Flying Speculation and America's First Banking Collapse,,(Viking 2008); Jane Knodell, The Second Bank of the United States: “Central” Banker in an Era of NationBuilding, 1816-1836 (Routledge, 2016).

${ }^{30}$ Articles of association of the Bank of Central New-York, at Utica; and the General Banking Law of the State of NewYork. Bank of Central New York (R. Northway, printer, 1838).

${ }^{31}$ Bray Hammond, Sovereignty and an Empty Purse: Banks and Politics in the Civil War (Princeton University Press, 1970); Richard Franklin Bensel, Yankee Leviathan: The Origins of Central State Authority in America, 18591877 (Cambridge University Press, 1990); Daniel P. Carpenter, The Forging of Bureaucratic Autonomy: Reputations, Networks, and Policy Innovation in Executive Agencies, 1862-1928 (Princeton University Press, 2001); Mashaw, "Federal Administration and Administrative Law in the Gilded Age;" Novak, The Myth of the "Weak' American State." 32 Jerry Mashaw, "Administration and 'The Democracy': Administrative Law from Jackson to Lincoln, 1829-1861," Yale Law Journal 117 (2008).
} 
institution's note redemption practices. Further, preliminary evidence suggests that, after President Andrew Jackson extinguished the Second Bank of the United States, the federal government may also have exercised some oversight of the financial system through the Independent Treasury.33 Meanwhile, scholars are reanimating an older debate about what function federal supervision, as constructed by Congress in the National Bank Acts, was meant to serve. As discussed above, Menand argues that supervision underlay the federal grant to national banks of a monetary franchise. Menand also recognizes that national bank notes were fully backed by U.S. bonds, obviating the need for supervision to secure the circulating medium. 34 Here, Bray Hammond's insight, that Congress and the Lincoln administration had very fuzzy ideas about the currency system they were trying to create, rings true; or more generously, that compromise in wartime yielded a highly imperfect but functional enough outcome. 35 To learn more, historical attention must shift from the legal foundation established by Congress to the institutions federal bureaucrats built, inviting analysis of how-and ifsupervisors forged institutional autonomy. ${ }^{36}$

The founding of the national banking system during the Civil War provides clear entry points into the large and ongoing debate about the development of the American state. Likewise, turning to the late nineteenth-century suggests a host of questions about the development of the supervisory structure in relation to the U.S. political economy. ${ }^{37}$ One way to organize these questions is to return to Figures 1 and 2 in the supervisory typology above. To some extent, the external paradigm is easier to address, in so far as the powers supervisors possessed are readily identifiable in the National Bank Acts and subsequent statutes. But questions remain. The first, of course, is why Congress expanded supervisory authority when it did? Or, as more accurately reflects the evidence, why Congress made little change to the supervisory structure despite clear indication that its original design was flawed? A generation of Comptrollers lamented their weak authority and limited capacities to shape bank behavior, but major reform only came with the Federal Reserve Act in $1913 .{ }^{38}$ A second set of questions relate, then, to how supervisors determined when to use the powers they possessed. To take one example, examiners were empowered to close insolvent institutions. But how, in the absence of congressional guidance,

\footnotetext{
33 Richard H. Timberlake, “The Independent Treasury and Monetary Policy before the Civil War," Southern Economic Journal 27, no. 2 (1960): 92-103.

34 Menand, "Why Supervise Banks?"

35 Hammond, Sovereignty and an Empty Purse.

${ }^{36}$ Carpenter, Forging Bureaucratic Autonomy.

37 Richard Franklin Bensel, The Political Economy of American Industrialization, 1877-19oo (Cambridge University Press, 2000).

${ }^{8}$ Annual Report of the Comptroller of the Currency (1865-1912).
} 
did they define and determine insolvency? What did these mechanisms of legal obedience look like and how did they work in practice?39

Related, but more challenging still, are the internal paradigms-not just how supervisors changed bank behavior but why. Pinning down the practice of supervision in this context is a challenging but important effort. Did supervisors conceive of their role as public-facing and visible, as potential "confidence legitimators," to use Menand's term?40 Or, more consistent with emerging trends toward legal formalism, did they retreat from view? ${ }^{41}$ Were supervisors, as proto-management consultants, catalysis for banker professionalization? Or did bankers selfprofessionalize, by creating private institutions like the American Bankers Association (1875), in opposition to supervisory intrusion? Did supervisors actively seek to prevent financial crises? Did they encourage or discourage alternative crisis prevention methods, like deposit insurance, central banking, and clearinghouses? ${ }^{42}$ From the birds-eye-view provided by the Comptroller's annual reports, it seems clear that Comptrollers were, in words of Robert Weibe, "searching for order," and doing so, following Dan Rodgers, not only from a provincial, U.S. viewpoint, but with a keen eye to international examples. 43 Indeed, supervision interweaves with still-vibrant debates about the nature of the American state and its relationship to the Gilded Age economy. Were bank supervisors agents of a "progressive" state, and if so, what kind of progressivism did they represent?

If scholars don't yet have good answers to these questions from a supervisory perspective, they have paid careful attention to the convergence of banking theory and government oversight in the 1913 Federal Reserve Act and in the subsequent actions of the Federal Reserve Board and regional banks.44 From the founding of the Fed, however, most

\footnotetext{
39 For an examination of this question during the 1930 s banking crises, see: Gary Richardson, "Categories and Causes of Bank Distress during the Great Depression, 1929-1933: The Illiquidity versus Insolvency Debate Revisited," Explorations in Economic History 44, no. 4 (October 1, 2007): 588-607.

40 Menand, "Why Supervise Banks?," 24-25; Kris James Mitchener and Matthew Jaremski "The Evolution of Bank Supervision: Evidence from U.S. States,” Journal of Economic History 75 (2014).

${ }^{41}$ Morton J. Horwitz, "The Rise of Legal Formalism," The American Journal of Legal History 19, no. 4 (October 1975): 251-264; Balogh, Government Out of Sight.

${ }^{42}$ Sprague, History of Crises under the National Banking System; John A. James and David F. Weiman, "The National Banking Acts and the Transformation of New York City Banking During the Civil War Era,” The Journal of Economic History 71, no. 2 (2011).

43 Robert H Wiebe, The Search for Order, 1877-1920 (Hill and Wang, 1967); Daniel T. Rodgers, Atlantic Crossings: Social Politics in a Progressive Age (Belknap Press of Harvard University Press, 1998). The publications of the National Monetary System provide rich evidence for this, and are available here:

https://fraser.stlouisfed.org/series/publications-national-monetary-commission-series-1493. See also J. Lawrence Broz, The International Origins of the Federal Reserve System (Cornell University Press, 1997).

44 James Livingston, Origins of the Federal Reserve System: Money, Class, and Corporate Capitalism, 189o-1913 (Cornell University Press, 1986); M. Elizabeth Sanders, Roots of Reform: Farmers, Workers, and the American State, 1877-1917 (University of Chicago Press, 1999); Peter Conti-Brown, The Power and Independence of the Federal Reserve (Princeton University Press, 2016).
} 
historical emphasis has focused squarely on monetary policy. Supervision and the Comptroller largely slip from view. 45 The title of the Act, however, promised "more effective supervision." What this meant in practice has not yet been explored. For example, scholars have largely ignored the ways that the Federal Reserve Banks exercised supervision through discount policy. Here, two key words are important. "Eligibility" was a regulatory standard that governed which assets Fed banks could discount, rules structured around the real bills doctrine and asset liquidity. "Acceptability," meanwhile, was a supervisory standard, focused on credit quality. When a Federal Reserve Bank discounted bank collateral it took on the credit risk, and case-bycase acceptability decisions protected Fed banks from taking on too much risk. But acceptability, like eligibility, served a larger role, encouraging particular bank lending practices favored by the Reserve Banks. Through the vehicle of acceptability, the regional Feds encouraged member banks-all national banks and some state banks-to modernize their lending practices, compelling them to gather balance sheet and cashflow information from borrowers for whom a hand shake had previously been sufficient. Thus, the Federal Reserve became an agent of business modernization, providing not only more effective supervision of banks, but more effective market surveillance across the economy. ${ }^{46}$

Loan modernization, as against older practices of "character" lending, was just one of many points of conflict between the Federal Reserve, the Comptroller of the Currency, and statesupervisory officials. The founding of the Fed thus launched what would become the major theme in supervision for the remainder of the twentieth century: supervisory competition. Certainly, competition had already existed among the Comptroller and the states, a contest memorably framed by Acting Comptroller Frances G. Awalt as "the competition in laxity." 47 Federal disharmony took this form, too, at times. Yet the Federal Reserve Act also initiated important reforms of examiner compensation, and the Comptroller eventually restructured national bank examination districts around Federal Reserve districts, creating more efficient systems of information gathering and sharing. The currents and counter currents of agency cooperation and competition remain live themes in practice down to the present, and the founding of the Federal Reserve is a prime moment to begin considering how institutional

\footnotetext{
45 Friedman and Schwartz, Monetary History; Allan H. Meltzer, A History of the Federal Reserve: Volume I, 19131951 (Chicago, 2003); Charles Kindleberger, The World in Depression, 1929-1939 (University of California Press, 1986); Barry J. Eichengreen, Golden Fetters: The Gold Standard and the Great Depression, 1919-1939 (Oxford University Press, 1992). But cf. Eugene Nelson White, The Regulation and Reform of the American Banking System, 1900-1929 (Princeton University Press, 1983).

${ }^{46}$ Conti-Brown and Vanatta, Risk and Discretion.

47 White, The Regulation and Reform of the American Banking System; Mitchener and Jaremski, "The Evolution of Bank Supervisory Institutions;" Annual Report of the Comptroller of the Currency (1932), 4.
} 
design and evolution has yielded cooperation at times, competition at times, and consistency almost never.

The founding of the Fed is also, of course, the first act in the great drama of the Great Depression. On the eve of that cataclysm, supervisory disharmony was readily apparent. The Federal Reserve, concerned with national monetary policy and individual reserve bank solvency, was not yet willing to use its balance sheet to aggressively confront the crisis. The Comptroller (and the state supervisors) had greater oversight responsibility but little positive authority to aid troubled banks or a troubled banking system. There were exceptions. In examinations of the emergency lending activities of the Federal Reserve Bank of Atlanta in the 1920s and 1930s, Gary Richardson and co-authors show how an activist and dramatic discount policy could ensure bank survival in moments of crisis. ${ }^{8}$ The Atlanta Fed's actions, Richardson, et. al., find, hinged on its unique "acceptability" practices and the very visible crisis fighting - at times involving airplanes full of cash—of its president, Eugene Black. Yet, overall, despite the reforms promulgated by the Federal Reserve Act, supervision was ill prepared to confront the crisis. While this is readily apparent, the supervisory response to crisis, until very recently, has been entirely ignored. Indeed, monetary historians pulled the air out of the room. 49

Of course, the Depression created the conditions necessary for major political-economic reform, embodied in Franklin D. Roosevelt's New Deal. The New Deal, was, in this vein, a major watershed for supervision, perhaps as important as the founding of the Comptroller two generations earlier. From his first days in office, Roosevelt coupled the expertise and experience of bank supervisory officials to his locomotive of political legitimacy. Through the 1933 Bank Holiday, Roosevelt empowered officials to act decisively and set the stage for revived institutions like the Comptroller and Reconstruction Finance Corporation, and new ones, like the Federal Deposit Insurance Corporation, to engage in continuous and vigorous federal oversight of the financial system..$^{\circ}$ Similar to the founding of the Comptroller during the Civil War, the New Deal reforms of supervision map onto consensus narratives about the development of American governance. Surveying "What the New Deal Did,” historian David Kennedy argues that above all,

\footnotetext{
${ }^{48}$ Gary Richardson and William Troost, "Monetary Intervention Mitigated Banking Panics during the Great Depression: Quasi-Experimental Evidence from a Federal Reserve District Border, 1929-1933," Journal of Political Economy 117, no. 6 (December 2009); Mark Carlson, Kris James Mitchener, and Gary Richardson, "Arresting Banking Panics: Federal Reserve Liquidity Provision and the Forgotten Panic of 1929," Journal of Political Economy 119, no. 5 (October 2011): 889-924.

49 Conti-Brown and Vanatta, "Logic and Legitimacy;" Friedman and Schwartz, Monetary History; Meltzer, A History of the Federal Reserve: Volume I; Kindleberger, The World in Depression; Eichengreen, Golden Fetters; Peter Temin, Did Monetary Forces Cause the Great Depression? (W. W. Norton, 1976). Cf. Susan Estabrook Kennedy, The Banking Crisis of 1933 (University Press of Kentucky, 1973).

5o William L. Silber, "Why Did FDR's Bank Holiday Succeed?," Federal Reserve Bank of New York Economic Policy Review (July 2009): 19-30
} 
it provided Americans security, and that supervisory institutions played a critical role in that project. ${ }^{51}$ Yet, while the New Deal remains a deep furrow of historical scholarship, banking reform has never been at the forefront of the agenda. $5^{2}$ Looking back from the stability of the early postwar era, historians largely accepted as New Deal financial reforms as successful, without examining closely what, in the case of supervision, those reforms actually entailed.

For instance, while the New Deal was undoubtedly a breakthrough, through which supervision gained new visibility and legitimacy, persistent counter currents remained which limited the scope of reform. Bankers remained deeply distrustful of the New Deal state, supervisory authority continued to overlap in counterproductive ways, and supervisory discretion created confusion inside and outside government about what supervisors would and should do. "We have as many banking systems as there are examiners," Undersecretary of the Treasury (and later University of Chicago economist) Jacob Viner complained to Henry Morgenthau in October 1934.53 Although the New Deal expanded federal authority over statechartered banks, it did not share the Civil-War era ambition to discard the state banking system entirely. Instead, state banking officials, in line with their federal counterparts, gained more power. ${ }^{4}$ At the same time, federal efforts to consolidate supervisory authority repeatedly failed. ${ }^{55}$ So too did efforts to recast supervision as a tool for Keynesian, countercyclical economic policy. $5^{6}$ The New Deal revolution was thus a conservative one, generating more administrative authority for the state (and states), but also retaining institutional disharmony among supervisory officials.

Nevertheless, Roosevelt's artful combination of political legitimacy and supervisory expertise set the stage for the multiplication of supervisory duties in the postwar era. In many ways, this expansion continued to map closely to consensus historical narratives about the burgeoning American state, even as Congress, contrary to other policy areas, continued to pursue New Deal inflected reforms. ${ }^{57}$ First, in the 1950 os and 1960s, supervisory authority

\footnotetext{
${ }^{51}$ David M. Kennedy, "What the New Deal Did,” Political Science Quarterly 124, no. 2 (July 1, 2009): 251-68. $5^{2}$ There are exceptions, of course. See Ellis Wayne Hawley, The New Deal and the Problem of Monopoly: A Study in Economic Ambivalence, $2^{\text {nd }}$ ed. (Fordham University Press, 1995); Helen M. Burns, The American Banking Community and New Deal Banking Reforms, 1933-1935 (Greenwood Press, 1974); James Stuart Olson, Saving Capitalism: The Reconstruction Finance Corporation and the New Deal, 1933-1940 (Princeton University Press, 1988); Eric Rauchway, The Money Makers: How Roosevelt and Keynes Ended the Depression, Defeated Fascism, and Secured a Prosperous Peace (New York, 2015).

53 Jacob Viner, "Preliminary Report to Secretary Morgenthau on Bank Examinations," October 1, 1934, folder 7, box 50, Jacob Viner Papers, Princeton University Archives and Special Collections.

54 National Association of Supervisors of State Banks, Proceedings of the Annual Meeting (1933).

55 Weiss, The President's Man.

${ }^{5}$ Nelson, Jumping the Abyss.

57 Alan Brinkley, The End of Reform: New Deal Liberalism in Recession and War (Alfred A. Knopf, 1995).
} 
expanded in transparently financial areas. The Bank Holding Company Act of 1956, the Bank Merger Act of 1960, and the Financial Institutions Supervisory Act of 1966 all reflected efforts by Congress to continue the antimonopoly legacy of the New Deal while also expanding the enforcement authority of bank supervisors. $5^{8}$ This expansion of authority, however, also created new ground for conflict: perhaps because supervisors had more power over banks, they had more reason to fight over how that power would be used.59 In any case, closer attention to conflict and supervisory priorities in this period may better help explain both the durability of New Deal reform efforts and the building momentum for their reversal. ${ }^{60}$

\section{Supervision and Society}

Supervisory history sits at the heart of American financial governance, and on that ground alone it is poised to shape and reshape debates about the co-development of American finance and American financial oversight. Yet, supervisory history also offers new opportunities to examine finance in society-to look at the broader relationship between financial institutions, financial governance, and histories of race, class, and gender. These disciplines, along with intellectual history and the history of science, offer both new and important questions about the activities and motivations of American governance, and interpretive tools with which to make sense of those questions.

Let's consider, again, the internal paradigms of supervision, what supervisors thought they were doing. Throughout the nineteenth century and down to the present, these paradigms were not only the function of trends in law and governance, but also deeply enmeshed in ideas what about constituted sound banking and in social norms governing everything from professional etiquette to racial hierarchies. So: When an examiner entered a bank-in the 1860, 1910s, 1960s-what did they look for? What did they prioritize? How did they evaluate a bank's loan portfolio? Or its management? Were they hungry? Had they skipped dinner? Were they drunk ${ }^{61}$ How did they learn to be an examiner in the first place? How did supervisory manuals guide their practices?62 What were their career ambitions? How did evaluation practices change

\footnotetext{
${ }^{8}$ John C. Deal, “Bank Regulatory Enforcement-Some New Dimensions,” The Business Lawyer 40, no. 4 (1985): 1319-33.

59 Mark H. Rose, Market Rules: Bankers, Presidents, and the Origins of the Great Recession (University of Pennsylvania Press, 2018).

${ }^{60}$ Steve Fraser and Gary Gerstle, The Rise and Fall of the New Deal Order, 1930-1980 (Princeton University Press, 1989).

61 "Cosmopolitan National Bank," Wall Street Journal, September 10, 1908.

62 There is a dynamic literature emerging about the role manuals and handbooks play in the production and construction of knowledge. See, for example, Angela Creager, Mathias Grote, and Elaine Leong, "Learning by the
} 
over time? To what extent were they inflected with ideas about racial difference, or ethnoreligious stereotypes? ${ }^{63}$ To what extent did they shape who got credit, when, and for how long? To what extend did they matter at all, at the mean and at the margin?

The questions might go on indefinitely, and perhaps we better see the advantage in asking them by trying to answer one. How did examiners evaluate a bank's loan portfolio? In the early post-Civil War years, Comptroller Hugh McCulloch encouraged bankers to make small loans in relation to their capital, to distribute them widely in their communities, and to record them assiduously, and examiners appear to have evaluated banks on this criteria. ${ }^{64} \mathrm{McCulloch}$ 's instructions guided examination practice for a generation, but they provided little guidance on how to evaluate credit quality or determine bank solvency. By the 1890 , examiners developed a scale for evaluating questionable loans, ranging from slow, to doubtful, to loss, roughly corresponding to illiquidity on one end and poor credit quality on the other (that it took more than three decades to devise a rating scale should not pass without comment). ${ }^{65}$ Examiners used the categories in predictable way, to correct bankers and urge them to better lending practices. But they also used loan criticism in surprising ways. With a "slow" designation from an examiner, a banker could twist the arm of a reluctant borrower. Sound lending, moreover, not only depended on economic and legal categories, but racial ones as well. After inspecting one Southern bank in the 1920s, an examiner criticized the bank's loans to black framers, explaining, "[t]he negro as a rule is poor pay and does not try to accumulate money and get ahead."66

There is a larger point here than simply showing that some examiners were racist, although given the longstanding relationship between credit access and economic citizenship in the United States, that point should not be minimized. ${ }^{67}$ Rather, it is that our historical

Book: Manuals and Handbooks in the History of Knowledge,” Max Plank Institute for the History of Science (20152019), https://www.mpiwg-berlin.mpg.de/research/projects/learning-book-manuals-and-handbooks-historyknowledge.

63 Rebecca Kobrin, "Too Big to Fail in 1930: The Failed Bank of United States and the Long Shadow of East European Jewish Immigrant Banking," American Jewish History 103, no. 4 (October 2019): 457-483.

${ }^{64}$ Hugh McCulloch, Instructions and Suggestions of the Comptroller of the Currency in Regard to the Organization and Management of National Banks, (Government Printing Office, 1864), TK; R. W. Derrickson, [Bank Examiners Book] (1868), University of Pittsburgh Library.

${ }_{5}$ Annual Report of the Comptroller of the Currency (1934), 3-4; Leo T. Crowley to Marriner S. Eccles, 9 Feb. 1938, Morgenthau Diaries, Book 120, 289, http://www.fdrlibrary.marist.edu/_resources/images/morg/mdo158.pdf; Walter A. Morton, "Liquidity and Solvency," The American Economic Review 29, No. 2 (June 1939): 279.

66 Federal Reserve, Committee on Branch, Chain, and Group Banking, "225 Bank Suspensions: Case Histories from Examiners' Reports,” May 1933, TK, https://fraser.stlouisfed.org/title/797.

${ }_{67}$ Louis Hyman, Debtor Nation: The History of America in Red Ink (Princeton University Press, 2011); Monica Prasad, The Land of Too Much: American Abundance and the Paradox of Poverty (Harvard University Press, 2012); Gunnar Trumbull, Consumer Lending in France and America: Credit and Welfare (Cambridge University Press, 2014). 
knowledge of the American financial system relies in significant part on data collected by or under the auspices of the supervisory structure. Following historians of science, we need to attend to how those facts were created, recognizing that pristine banking theory routinely collided with the social, cultural, and even physical worlds of bank supervisors. ${ }^{68}$ We can also follow historians of gender and sexuality in their observation that government officials often created ad hoc and arbitrary categories, which, once given bureaucratic designation, gain the force of law. 69

The relationship between supervision and categories of race and gender became much more visible when, in response to the social movements of the 1960s-especially civil rights, feminism, and third wave consumerism-Congress sought to leverage supervisory credibility in the service of social reform. Legislation like The Truth in Lending Act (1968), the Fair Credit Reporting Act (1970), the Fair Credit Billing Act (1974), the Equal Credit Opportunity Act (1974), and the Community Reinvestment Act (1977) all charged bank supervisory agencies with overseeing social policy priorities. By the late 1970s, bank examiners in the field and bank supervisors in Washington pursued policies as diverse as price disclosure, anti-discrimination, and adequate community investment, while also continuing to monitor bank safety and soundness (not to mention money laundering and, eventually, internationally agreed capital requirements). $7^{0}$

While historians have written extensively about the 1960 s social movements, scant attention has been paid to how supervisors implemented these policies, or, likewise, how these new priorities reshaped supervision. ${ }^{71}$ Supervisors, broadly speaking, were hostile to new social mandates, both during the legislative process and in implementation. These mandates were, supervisors argued, at odds with their core missions-and with their internal self-conceptions. By generating large penalties for offending banks, consumer compliance could, for example, endanger safety and soundness. In practice, supervisory agencies often separated safety-andsoundness and compliance examinations, which may have created new lines of interagency disharmony, not to mention minimizing social policies as enforcement priorities. Yet, the history of supervision, in this case-as in many others-remains understudied. How were social

\footnotetext{
68 Angela N. H. Creager, Elizabeth Lunbeck, and M. Norton Wise, Science without Laws: Model Systems, Cases, Exemplary Narratives (Duke University Press, 2007).

69 Margot Canaday, The Straight State: Sexuality and Citizenship in Twentieth-Century America (Princeton University Press, 2009).

$7^{70}$ Charles A. E. Goodhart, The Basel Committee on Banking Supervision: A History of the Early Years, 1974-1997 (Cambridge University Press, 2011).

${ }^{71}$ For representative works, see Lizabeth Cohen, A Consumer's Republic: The Politics of Mass Consumption in Postwar America (Vintage Books, 2003); Julian E. Zelizer, The Fierce Urgency of Now: Lyndon Johnson, Congress, and the Battle for the Great Society (Penguin Press, 2015).
} 
movement goals converted into governance practices through supervision? ${ }^{72}$ How did established supervisory bureaucracies adapt to these new mandates?73 To what extent did bank resistance to compliance fuel anti-government animus in general and deregulatory politics in particular?

Examining such questions may also invite scholars to consider the complicity of supervisory agencies in enforcing the racist and sexist policies which motivated social movements in the first place. To what extent did bank supervisors encourage the Federal Housing Administration loans that facilitated racial apartheid in the suburbs in the 1940s, 1950s, and 1960s?74 To what extent did they encourage consumer credit policies that denied credit to married women over the same period?75 Attention to these questions could add greater depth to what scholars already know about the active policies of racial and gendered exclusion promoted by the federal government in the postwar era. ${ }^{76}$

\section{Conclusion}

In any case, the expansion of federal authority generated by 1960 social movements was met with increasing resistance among financial institutions, and later policymakers, during the growing movement for deregulation and financialization through the 1970s and 1980s. Looking forward, supervisory histories will also-in light of the 2008 financial crisis-ask whether "desupervision" represented a distinct, if complementary, process to deregulation. In this area, as in many others, the historical study of supervision will throw light on the ways federal and state authorities have sought to influence bank behavior in the past, and on why the current tangle of supervisory institutions and powers exists as it does in the present. As this essay has demonstrated, moreover, histories of supervision would contribute to ongoing debates in a variety of historical disciplines, most especially those concerned with American financial and

\footnotetext{
${ }^{72}$ Rebecca K. Marchiel, After Redlining: The Urban Reinvestment Movement in the Era of Financial Deregulation (University of Chicago Press: 2020).

73 Brian Balogh, Chain Reaction: Expert Debate and Public Participation in American Commercial Nuclear Power, 1945-1975 (Cambridge University Press, 1991); Andrew Hoffman, From Heresy to Dogma: An Institutional History of Corporate Environmentalism (Stanford University Press, 2001).

74 Kenneth T. Jackson, Crabgrass Frontier: The Suburbanization of the United States (Oxford University Press, 1985); David M. P. Freund, Colored Property: State Policy and White Racial Politics in Suburban America (University of Chicago Press, 2007).

75 Felicia Kornbluh, The Battle for Welfare Rights: Politics and Poverty in Modern America (University of Pennsylvania Press, 2007); Hyman, Debtor Nation.

${ }^{76}$ Ira Katznelson, When Affirmative Action Was White: An Untold History of Racial Inequality in TwentiethCentury America (W.W. Norton, 2005).
} 
regulatory governance, but also those interested in the racial and gendered limits to economic citizenship, and many others.

To some extent, historians, driven by renewed interest in American governance and the history of capitalism, are already converging on financial history as major area of historical inquiry, and as such are likely to stumble into the dark corners of supervision sooner or later. Supervisory institutions would do well to light their way, but this will require investments of time and of money. Most obviously, federal agencies should review the standards governing Confidential Supervisory Information in an effort to make more source material available for scholarly investigation. They should also work to open up their archives, in the case of the Federal Reserve Banks, and to work with the National Archives to process and open supervisory material housed there. They should digitize more material and make their current digitization resources more functional. And they should encourage commercial banks to follow the lead of their peers abroad, and likewise open up and digitize archives. Second, supervisory agencies should hire Ph.D. historians to explicitly take up research on social and cultural topics, and they should fully incorporate those historians into their research staffs. Historians will bring new questions and modes of inquiry that improve the overall research product of these staffs.

Supervision is ultimately the product of history. Its institutional form and oversight practices-its internal and external paradigms-have been and remain fluid, shaped by the bright lines of law and the opaque inclinations of supervisory officials. Uncovering that history stands to invigorate historical debates about the past and make supervision more comprehensible in the present. 